\title{
EFFECT OF SHADING ON SURVVAL AND GROWTH OF Mesua (CLUSIACEAE) AND Shorea (DIPTEOCARPACEAE) SEEDLINGS ACROSSTOPOGRAPHIC GRA.DIENT IN SINHARAJA RAIN FOREST, SOUTHWEST SRI LANKA
}

\author{
E.P.S.K. Ediriweera1, B.M.P.Singhakumara1 \& P.M.S.Ashton² \\ ${ }^{1}$ Department of Forestry and Environmental Science, \\ University of Sri Jayewardenepura \\ 2 Yale University, New Haven, U.S.A.
}

\begin{abstract}
The effect of shading on survival and growth of two species of Mesua (Clusiaceae) and four species of Shorea (Dipteocarpaceae:) plaitted seedlings were investigated at different topographic positions in Sinharaja rain forest. All occur together as canopy dominant trecs in Sinharaja rain forest. Twelve-understory sites were selected, four each on different topographic positions: valley, midslope and ridgetop. Measurements of height, number of leaves, root collar diameter and the mortality were recorded over a five-year period. Hemispherical canopy photographs were taken to calculate Indirect Site Factor (ISF), Direct Site Factor (DSF), and the Leaf Area Index (LAI). Analysis of photographs demonstrated that LAI decreased from valley to ridge top while DSF and ISF increased from the valley to ridge top. After five years thirty-four (34\%) seedlings died in the ridge top and the lowest mortality was recorded in the midslope. Seedlings of Mesua ferrea $\mathrm{L}$. had the highest survival than other species in all understory conditions and the lowest survival rate recorded for Shorea trapezijolia (Thw:) Ashton. Results showed clear differences in survival and growth among spccies. These differences appeared related to availability of soil moisture and understory radiation regimes.
\end{abstract}

Proceedings of the Eighth Annual Forestry and En ironment Symposium 2002 of the Department of Forestry and Environmental Science, Unive rsity of Sri Jayewardenepura, Sri Lanka 